\title{
Detection of the Pinewood Nematode, Bursaphelenchus xylophilus, Using a Real-Time Polymerase Chain Reaction Assay
}

\author{
A. X. Cao, X. Z. Liu, S. F. Zhu, and B. S. Lu \\ First and second authors: Key Laboratory of Systematic Mycology and Lichenology, Institute of Microbiology, Chinese Academy of \\ Science, Beijing 100080, P.R. China; first and fourth authors: Department of Plant Pathology, Shanxi Agricultural University, Taigu, \\ Shanxi 030801, P.R. China; and third author: Beijing Animal and Plant Quarantine Bureau, Beijing 100029, P.R. China. \\ Accepted for publication 14 January 2005.
}

\begin{abstract}
Cao, A. X., Liu, X. Z., Zhu, S. F., and Lu, B. S. 2005. Detection of pinewood nematode, Bursaphelenchus xylophilus, using a real-time polymerase chain reaction assay. Phytopathology 95:566-571.

The pinewood nematode, Bursaphelenchus xylophilus, has caused significant damage to pine plantations both in East Asia and North America and is an important quarantine organism. A real-time polymerase chain reaction (PCR) assay was developed to detect B. xylophilus. A set of primers and probe specific for B. xylophilus was designed to target the
\end{abstract}

ABSTRACT ribosomal DNA internal transcribed spacer region. Optimal primer concentration, $\mathrm{Mg}^{2+}$ concentration, and extension temperature were $400 \mathrm{nM}$, $3.0 \mathrm{mM}$, and $60^{\circ} \mathrm{C}$, respectively. The assay was highly specific and sensitive, detecting as little as $0.01 \mathrm{ng}$ of $B$. xylophilus DNA. The real-time PCR assay also successfully detected B. xylophilus in field samples, and it should be very useful for quarantine purposes.

Additional keywords: cycle threshold, normalized fluorescence.
The pinewood nematode, Bursaphelenchus xylophilus (Steiner $\&$ Buhrer) Nickle $(=B$. lignicolus $)$, is the casual agent of pine wilt disease $(18,19)$, an important disease to conifer trees. The nematode is native to North America and has been associated with pine wilt in Canada, Mexico, and the United States $(5,7,14,23)$. B. xylophilus may have been introduced into Japan from North America in the early 1900s and subsequently introduced into China and Korea from Japan $(8,30)$.

The European Plant Protection Organization placed the pinewood nematode on the A1 list of quarantine pests in July 1985 (25); the nematode, however, was reported in Portugal in 1999 (22). During the 1990s, this quarantine on green lumber exports to Europe caused an estimated annual loss to the American forest industry of US $\$ 100$ million (9).

In China, the pinewood nematode was first detected in Jiangsu in 1982 and was subsequently reported in Guangdong, Anhui, Shandong, Zhejiang, Hongkong, and Taiwan (33). From 1985 to 1995, B. xylophilus destroyed approximately one million pine trees in China (24). To prevent its further introduction and spread, B. xylophilus has been listed as a quarantine pest in China. Within the past decades, China has developed comprehensive regulations to eliminate significant pest risks associated with importing coniferous wood chips, unseasoned lumber, and $\operatorname{logs}$ from B. xylophilus-infested areas or countries.

Effective quarantine requires efficient detection. However, detection of $B$. xylophilus is complicated by B. mucronatus Mamiya \& Enda. B. mucronatus is widely distributed in Asia and Europe, is not pathogenic to pines under field conditions, but is morphologically similar to B. xylophilus $(8,20)$. The only major morphological difference between the species is the shape and size of a mucro on the tail of female $B$. mucronatus. The occurrence of interspecific forms also makes it difficult to distinguish between these two closely related species (28).

Corresponding author: X. Z. Liu; E-mail address: liuxz@ sun.im.ac.cn

DOI: 10.1094/PHYTO-95-0566

(C) 2005 The American Phytopathological Society
To distinguish B. xylophilus from B. mucronatus, researchers have developed DNA-based methods, including restriction fragment length polymorphism $(15,34)$, random amplified polymorphism DNA $(27,35)$, polymerase chain reaction (PCR) $(11,21,32)$, as well as DNA fingerprinting probes derived from the repeated DNA sequence elements $(11,28)$. Although these methods differentiate B. xylophilus from B. mucronatus, they are too time-consuming for quarantine purposes. A less time-consuming PCRbased assay, referred to as real-time PCR, has recently shown promise in the specific and rapid detection of bacteria $(3,26,29)$, fungi (6), and other organisms (2,31). This technique relies on the combination of a primer set and an additional dual-labeled fluorogenic probe (14) to enable continuous monitoring of amplicon synthesis during thermocycling; the technique requires no postPCR handling for target quantification (26).

In this paper, a B. xylophilus-specific real-time PCR assay was developed and optimized. The internal transcribed spacer (ITS) region was used because, although largely conserved, it differs between B. xylophilus and B. mucronatus $(4,15-17,21,22,34)$. Furthermore, the ITS sequence occurs in multiple copies in the genome and the sequence information is available in GenBank. The specificity, sensitivity, and application of the assay are demonstrated.

\section{MATERIALS AND METHODS}

Sources of nematodes and DNA samples. Nine isolates of Bursaphelenchus spp. were obtained from laboratory stocks and cultured on potato dextrose agar plates (Difco, Detroit, MI) colonized with the fungus Botrytis cinerea (Table 1). One isolate of Caenorhabditis elegans was supplied by the Caenorhabditis Genetics Center (Minneapolis, MN) and was cultured on nematode growth medium. Three DNA samples of Bursaphelenchus spp. were provided by W. M. Ye (University of New Hampshire, Durham).

DNA extraction. Two methods were used to extract genomic DNA from nematodes. When the DNA was extracted from a large number of nematodes (including mixed life stages within a spe- 
cies or mixed species), the method of Webster et al. (28) was used. When the DNA was extracted from one to four nematodes, the method of Zheng et al. (34) was used with the following modifications. One to four nematodes were placed into $15 \mu \mathrm{l}$ of double-distilled water on a glass slide and cut into small pieces with a sterile side-sharpened needle. The nematode fragments in $10 \mu \mathrm{l}$ of suspension were transferred into a sterile $0.5-\mathrm{ml}$ thinwalled PCR tube containing $8 \mu$ of nematode lysis buffer (12.5 mM KCl, $2.5 \mathrm{mM}$ Tris- $\mathrm{HCl}$ [pH 8.3], $0.03 \mathrm{mM} \mathrm{Mg}^{2+}$, $0.025 \mathrm{mM}$ dithiothreitol, $0.12 \%$ Tween 20 , and $1 \mu \mathrm{l}$ of proteinase $\mathrm{K})$. Tubes were incubated at $65^{\circ} \mathrm{C}$ for $60 \mathrm{~min}$ followed by $95^{\circ} \mathrm{C}$ for $3 \mathrm{~min}$.

DNA concentration was determined by measuring the absorbance at $260 \mathrm{~nm}$ with a SmartSpec 3000 spectrophotometer (BioRad Laboratories, Hercules, CA). If necessary, DNA was diluted with ultra-purified water.

ITS primers and TaqMan probe design. Genus-specific primers F194 (5'-CGTAACAAGGTAGCTGTAG-3') and 5368 (5'-TTTCACTCGCCGTTACTAAGG-3') were used to amplify the ITS1, 5.8S, and ITS2 rDNA region of Bursaphelenchus spp. (15). PCR products from five isolates each of B. xylophilus and $B$. mucronatus were cloned and sequenced. The nucleotide sequence of ITS1-5.8S-ITS2 region was submitted to the GenBank/
EMBL database (accession no. U92464), and related sequences were aligned using the ClustalX 1.81 package (PE Applied Biosystems, Foster City, CA). The DNA regions demonstrating the greatest dissimilarities between species were selected for designing B. xylophilus-specific PCR primers and TaqMan probe. The primers and TaqMan probe were designed using the software program Primer Express version 2.0 (PE Applied Biosystems). Primers and probe were synthesized by PE Applied Biosystems.

Real-time PCR assay. Real-time PCR was performed in 50- $\mu \mathrm{l}$ reactions using MicroAmp Optical 96-well plates and MicroAmp Optical Caps (PE Applied Biosystems). The 50- $\mu$ l PCR mixture consisted of $5 \mu$ of $10 \times$ reaction buffer $(1 \mathrm{mM}$ Tris-HCl [pH 9.0],

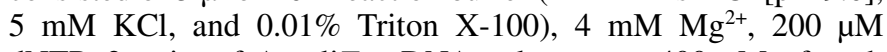
dNTP, 2 units of AmpliTaq DNA polymerase, $400 \mathrm{nM}$ of each primer, $200 \mathrm{nM}$ TaqMan probe, and $10 \mathrm{ng}$ of template DNA. As a negative control, ultrapure water rather than template DNA was included in each PCR run. Chemicals were purchased from Promega (Madison, WI). The ABI Prism 7700 Sequence Detection System (PE Applied Biosystems) was used for amplification and fluorescence measurement at each temperature step and cycle during the reaction. Thermal cycling conditions consisted of $10 \mathrm{~min}$ at $95^{\circ} \mathrm{C}$ followed by 40 cycles of $15 \mathrm{~s}$ at $95^{\circ} \mathrm{C}$ and then

TABLE 1. Isolates and origins of Bursaphelenchus species and Caenorhabditis elegans

\begin{tabular}{lccl}
\hline Nematode species & Isolate & Source of DNA template $^{\mathrm{a}}$ & \multicolumn{1}{c}{ Geographical location } \\
\hline B. xylophilus & BX1 & Juvenile & Guangdao, Shandong, China \\
B. xylophilus & BX2 & Juvenile & Nanjing, Jiangsu, China \\
B. xylophilus & BX3 & Juvenile & Nanjing, Jiangsu, China \\
B. xylophilus & BX4 & Juvenile & Guangzhou, Guangdong, China \\
B. xylophilus & BX5 & Juvenile & Langyanshan, Anhui, China \\
B. xylophilus & BX6 & DNA & Mito, Ibaraki, Japan \\
B. mucronatus & BM1 & Juvenile & Nanjing, Jiangsu, China \\
B. mucronatus & BM2 & Juvenile & Japan \\
B. mucronatus & BM3 & Juvenile & Grünberg, Germany \\
B. mucronatus & BM4 & Juvenile & Zusmarshausen, Germany \\
B. fraudulentus & BF & DNA & Zusmarshausen, Germany \\
B. tusciae & BT & DNA & Scopeti, Florence, Italy \\
C. elegans & CE11 & Juvenile & Caenorhabditis Genetics Center, Minneapolis, USA \\
\hline
\end{tabular}

${ }^{a}$ DNA was obtained either from juvenile nematodes in culture or as DNA from other laboratories.

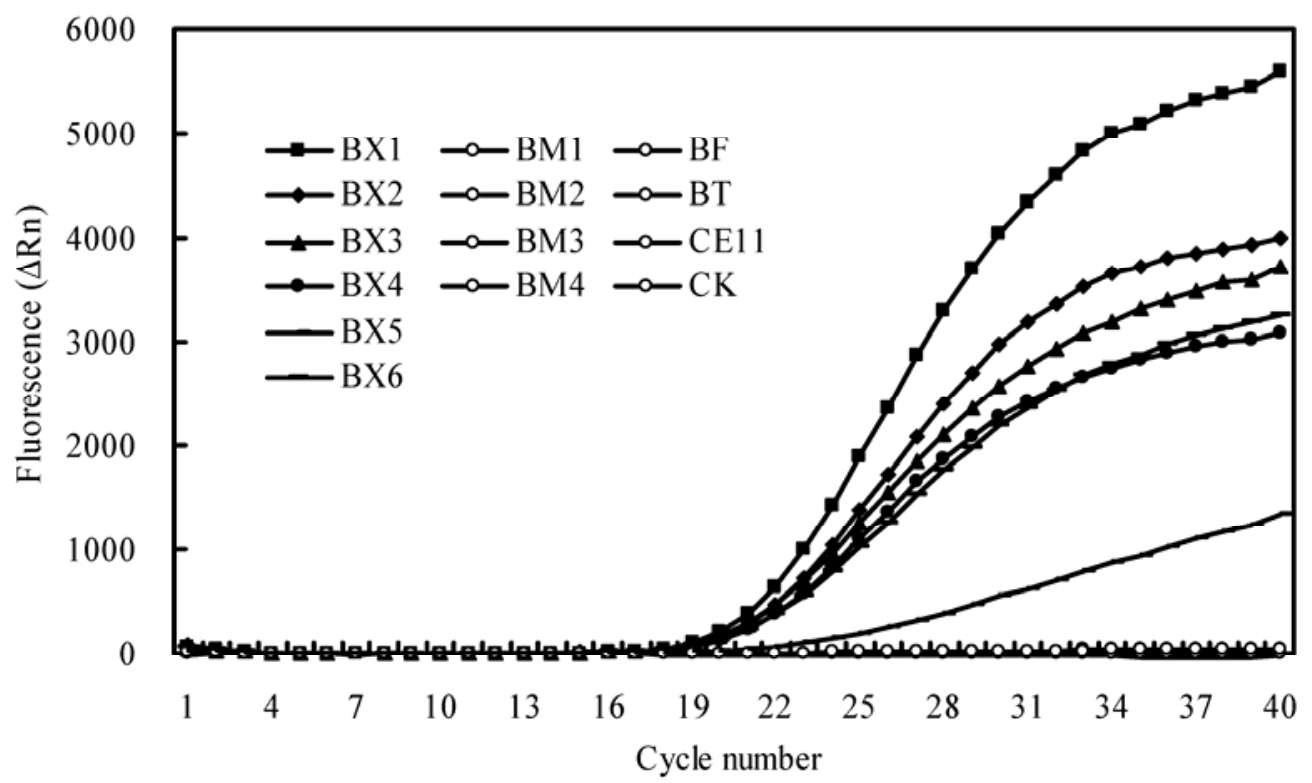

Fig. 1. Specificity of the real-time polymerase chain reaction assay for Bursaphelenchus xylophilus. The assays were conducted with $10 \mathrm{ng}$ of DNA template from B. xylophilus (BX1-BX6), B. mucronatus (BM1-BM4), B. fraudulentus (BF), B. tusciae (BT), or Caenorhabditis elegans (CE11) and using the B. xylophilusspecific primer set BXF and BXR and TaqMan probe BXT under optimized conditions. CK = control without DNA template. Representative data from 1 of 10 experiments are shown. To avoid overlapping and confusing symbols, the same symbol (-o-) was used for treatments that produced no fluorescence. 
$45 \mathrm{~s}$ at $60^{\circ} \mathrm{C}$. The ABI Prism Sequence Detector Software (version 1.6) was used to collect and analyze data of normalized fluorescence $(\Delta \mathrm{Rn})$ and cycle threshold $(\mathrm{Ct})$. The $\Delta \mathrm{Rn}$ value represents a difference in fluorescence intensity between two cycles; $\mathrm{Ct}$ refers to the specific cycle number at which the $\Delta \mathrm{Rn}$ value becomes greater than the base line. The $\mathrm{Ct}$ value is inversely proportional to the log of the initial template of DNA and has been shown to be the most reliable parameter to detect and quantify target DNAs with real-time PCR (13). Triplicates were performed in each experiment, and each experiment was repeated at least three times.

Optimal conditions were determined by performing the realtime PCR with concentration gradients of primers (50 to $800 \mathrm{nM}$ ) and $\mathrm{Mg}^{2+}(1.0$ to $4.5 \mathrm{mM})$ at different annealing and extension temperature $\left(55,58,60,61,62\right.$, and $\left.63^{\circ} \mathrm{C}\right)$. Conditions were considered optimal if they produced the smallest $\mathrm{Ct}$ values and the most fluorescence. Ten nanograms of genomic DNA of B. xylophilus isolate $\mathrm{BX} 2$ was used for optimization of conditions.

Specificity and sensitivities of $B$. xylophilus real-time PCR assay. DNA templates (10 ng each) extracted from isolates of B. xylophilus, other Bursaphelenchus spp., and C. elegans were used to examine the specificity of primers and probe using the optimized PCR parameters. To insure the integrity of DNA, the primers F194 and 5368 (15) were used to amplify all extracts except that from $C$. elegans; amplification was successful in each case (data not shown), indicating that the DNA from all Bursaphelenchus spp. was capable of amplification.

To determine the minimum DNA detection threshold, $100 \mathrm{ng}$ of genomic DNA of B. xylophilus (isolate BX2) was diluted serially (10-fold) until the target DNA could not be detected by real-time PCR. Triplicates of each concentration were amplified according to the optimal conditions described previously.
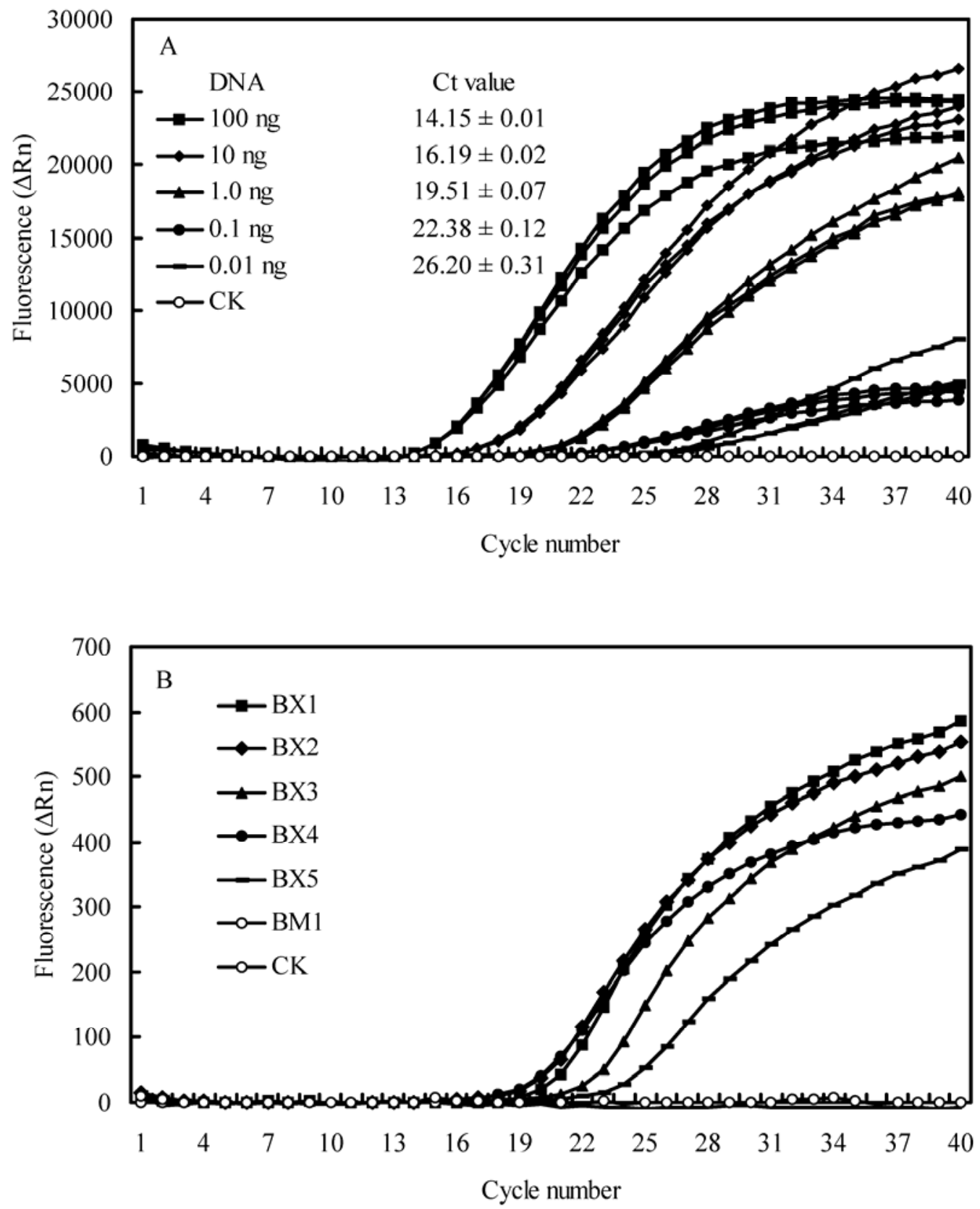

Fig. 2. Sensitivity of the real-time polymerase chain reaction assays for Bursaphelenchus xylophilus using A, a 10-fold dilution series of B. xylophilus (isolate BX2) genomic DNA or B, genomic DNA extracted from single nematodes of B. xylophilus or B. mucronatus. A includes three replications of each dilution, and Ct refers to the cycle number at which fluorescence first increased. B includes five individual nematodes of B. xylophilus (BX1-BX5) and one nematode of B. mucronatus (BM1). Representative data from one of three experiments (A) or one of six experiments (B) are shown. CK = control without DNA template. To avoid overlapping and confusing symbols, the same symbol (-o-) was used for treatments that produced no fluorescence. 
An experiment was conducted to determine whether the assay could detect genomic DNA extracted from single nematodes. DNA was extracted from individual nematodes of five B. xylophilus isolates and one isolate of $B$. mucronatus; a control without DNA was included. Real-time PCR was conducted as described previously, and the experiment was repeated six times.

Application of real-time PCR to field samples. Three pieces $(\approx 5$ by 8 by $1.5 \mathrm{~cm}$ ) of pinewood were collected from the trunks of symptomatic trees in each of four pine forests. The forests were located in Aobaodi (Zhejiang Province), Langxi (Anhui Province), Liyang (Jiangsu Province), and Nanjing (Jiangsu Province), China. In the laboratory, the phloem was removed and the xylem was cut into small blocks $(\approx 1$ to $2 \mathrm{~mm}$ ). One sample from each forest (approximately $20 \mathrm{~g}$ of xylem blocks) was placed on a Baermann funnel at room temperature. Nematodes were recovered after $2 \mathrm{~h}$.

From each sample, 10 to 20 nematodes were examined individually and identified to species based on morphology. One to four individuals of the same nematodes were then subjected to real-time PCR using the B. xylophilus-specific primers and probe. The remaining nematodes in each sample were collectively subjected to real-time PCR using the B. xylophilus-specific primers and probe.

\section{RESULTS}

Primers and TaqMan probe design. PCR amplification of the rDNA-ITS region from B. xylophilus and B. mucronatus generated products $784 \mathrm{bp}$ long. Nucleotide sequences of PCR products from five isolates of B. xylophilus were aligned; no substitutions were found (100\% similarity). Nucleotide sequences of PCR products from five isolates of $B$. mucronatus also were aligned; 26 substitutions were detected (99.7\% similarity). The pair-wise comparison of $B$. xylophilus and B. mucronatus sequences revealed 119-bp substitutions among 784-bp nucleotides (84.8\% similarity). The region unique to $B$. xylophilus and conserved across the five isolates of $B$. xylophilus was selected for the development of species-specific primers and a TaqMan probe reporter. The forward primer (BXF) and reverse primer (BXR) were $5^{\prime}$ GATGATGCGATTGGTGACT-3' (35 to 53 bp) and 5'-AACGACGCGAATCGAACC-3' (75 to $92 \mathrm{bp}$ ), which amplify the sequence from 54 to $74 \mathrm{bp}$ in the ITS1 region. The TaqMan sequencespecific probe (BXT) was 5'-CGGTTGCCGCGCATGATGG-3' (55 to $73 \mathrm{bp}$ ) and labeled at the $5^{\prime}$ end with fluorescent reporter dye 6-carboxy-fluorescein (FAM) and at the $3^{\prime}$ end with quencher dye 6-carboxy-tetramethhylrhodamine (TAMRA) (TaKaRa Bio Inc., Shiga, Japan).

The normalized fluorescent intensity of the reporter dye $(\Delta R n)$ was plotted against cycle number to graph PCR amplification and to determine the $\mathrm{Ct}$. The smallest $\mathrm{Ct}$ values (and maximum fluorescence) were obtained with $400 \mathrm{nM}$ forward primer,

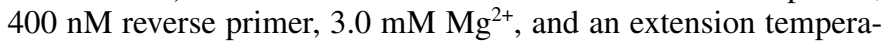
ture of $60^{\circ} \mathrm{C}$ (data not shown).

Specificity and sensitivity of TaqMan PCR primers and probe. The specificity of the primers and dual-labeled fluorescent probe was examined with genomic DNA extracted from six isolates of B. xylophilus, four isolates of B. mucronatus, and one isolate each of $B$. fraudulentus, $B$. tusciae, and $C$. elegans. PCR was conducted with 40 thermal cycles and the optimized conditions. All DNA extracts from B. xylophilus produced detectable fluorescence, whereas the DNA extracts from other nematodes produced no detectable fluorescence (Fig. 1).

The sensitivity of the real-time PCR assay was examined with a 10-fold dilution series of $100 \mathrm{ng}$ of B. xylophilus DNA and with DNA extracted from single nematodes. The PCR assay detected DNA template concentrations as low as $0.01 \mathrm{ng}$ (Fig. 2A). The $\mathrm{Ct}$ values were correlated with the DNA template concentration $\left(R^{2}=\right.$ 0.996 ), indicating the validity of the assay and its potential for quantification of target DNA. The PCR assay also detected DNA from single specimens of B. xylophilus (Fig. 2B).

Application of real-time PCR to field samples. Specimens of Bursaphelenchus spp. were recovered from all four samples of field-collected pinewood. Based on morphology, B. xylophilus but no other Bursaphelenchus sp. was present in two samples from Nanjing and Langxi, and both B. xylophilus and B. mucronatus were present in samples from Aobaodi $(72 \%$ B. xylophilus and $23 \%$ B. mucronatus) and Liyang $(64 \%$ B. xylophilus and $26 \%$ B. mucronatus). Bacterial-feeding nematodes were also found in all four samples. Genomic DNA from individual nematodes morphologically identified as B. xylophilus produced detectable fluorescence but genomic DNA from individual nematodes mor-

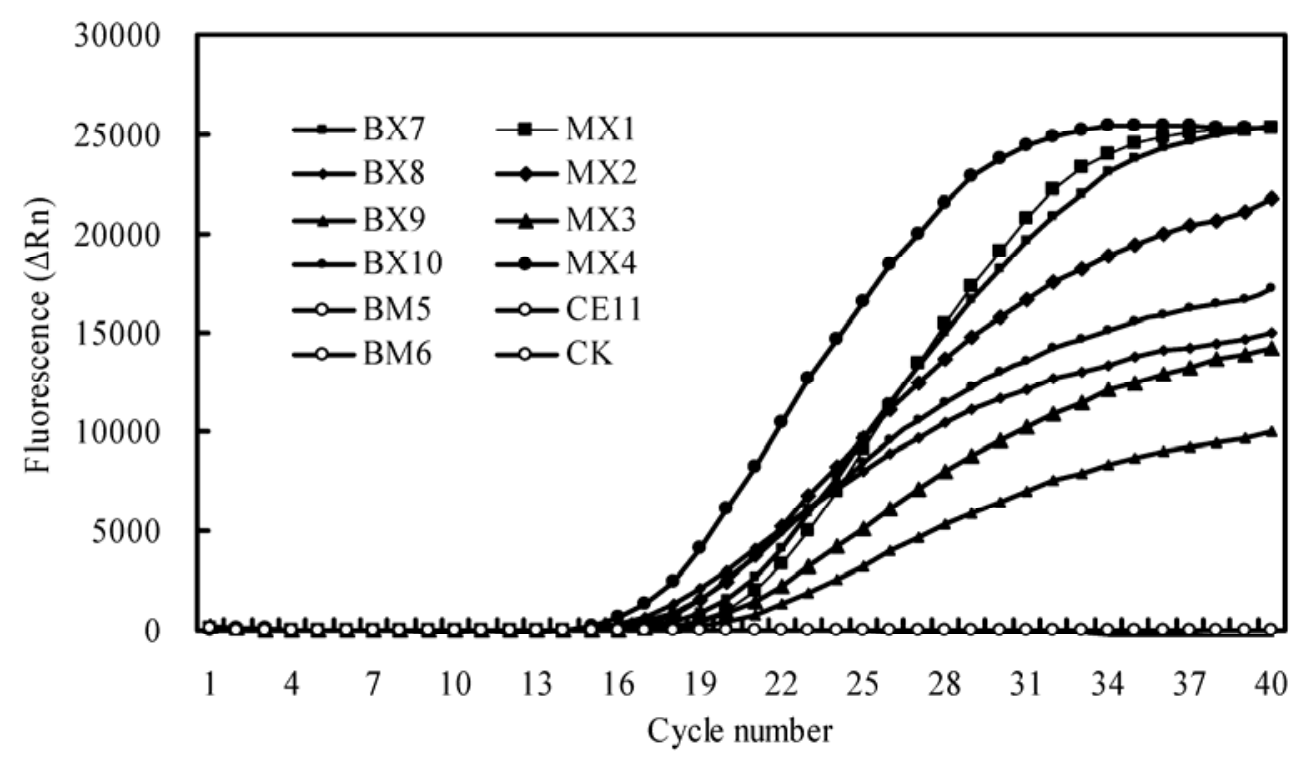

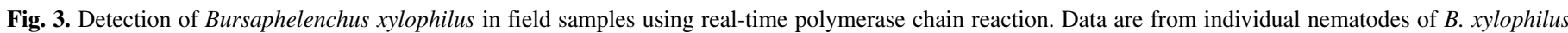

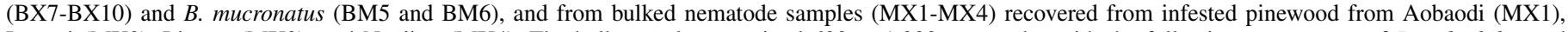

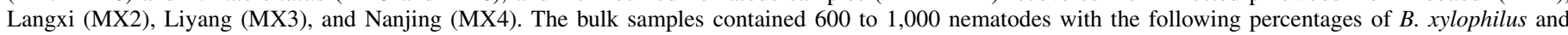

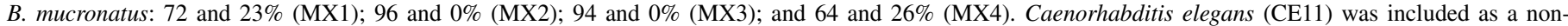

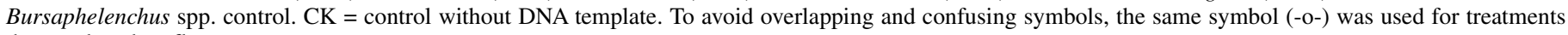
that produced no fluorescence. 
phologically identified as B. mucronatus did not (Fig. 3). The bulked nematode samples from Nanjing, Langxi, Aobaodi, and Liyang contained 600, 920, 1,001, and 780 nematodes, respectively. All of these bulked samples contained B. xylophilus and all produce detectable fluorescence (Fig. 3).

\section{DISCUSSION}

Long-distance transmission of B. xylophilus probably occurs with transportation of wood products including infested logs, packing boards, and wood chips $(9,10)$. Rapid and accurate detection of the nematode in these products is critical to prevent nematode introduction and is the basis for quarantine regulation $(1,16)$. Using morphology to detect $B$. xylophilus in pinewood is difficult because $B$. xylophilus is morphologically similar to related but nonpathogenic species. Molecular techniques such as DNA hybridization, restriction enzyme reactions, and PCR based on speciesspecific DNA fragments have been successfully used for detection and identification of Bursaphelenchus species, especially B. xylophilus and B. mucronatus $(4,12,15-17,21,22,32,34)$. But a major limitation of these previously described methods is that they are time-consuming, requiring at least $2 \mathrm{~h}$ per determination.

The real-time PCR assay developed in this study saves time because it is largely automated, it enables simultaneous analysis of up to 96 samples, and it requires no post-PCR gel electrophoresis. The fluorescent PCR technology also yields more robust results than other PCR methods (29) when small amplicons of 20 to $100 \mathrm{bp}$ in length are to be analyzed. Moreover, the assay was specific for B. xylophilus (it did not amplify DNA from other Bursaphelenchus species), was sensitive (it detected $0.01 \mathrm{ng}$ of template DNA), and detected B. xylophilus obtained from fieldcollected pinewood.

Although other nematodes present in pinewood could conceivably interfere with detection of $B$. xylophilus by real-time PCR, the diversity of nematodes in pinewood is limited. Only a few nematode species (B. xylophilus, B. mucronatus, and bacterivores) were found in our field samples, and the real-time PCR assay detected B. xylophilus in these bulk samples. For quarantine determinations, the testing of bulk nematode samples will certainly be more efficient than testing of individual nematodes.

The efficiency of the real-time PCR assay could be increased if we could eliminate the need to recover nematodes from pinewood, i.e., if nematode DNA could be extracted directly from the wood rather than from recovered nematodes. We tried several times to do this but failed (data not shown). A new machine, however, will soon decrease the time needed to recover nematodes from pinewood (C. S. Pan, personal communication), and this will further increase the usefulness of the real-time PCR assay.

\section{ACKNOWLEDGMENTS}

We thank S. Y. Chen, S. D. Li, R. Ma, and three anonymous reviewers for useful suggestions; W. M. Ye for providing DNA samples of Bursaphelenchus spp.; M. S. Lin, H. Xie, X. Y. Cheng, and L. F. Wang for providing nematode cultures; J. W. Zheng for providing an important reference; and the Caenorhabditis Genetics Center at the University of Minnesota for providing Caenorhabditis elegans. This research was supported by Chinese Academy of Sciences (Project no. KSCX1-SW-13-02-04).

\section{LITERATURE CITED}

1. Abad, P. 2000. Satellite DNA used as a species-specific probe for identification of Bursaphelenchus xylophilus. EPPO Bull. 30:571-574.

2. Alvin, G. E., Seoh, M. L., and Wong, S. M. 2000. Simultaneous quantitation of two orchid viruses by the TaqMan real-time RT-PCR. J. Virol. Methods 87:151-160.

3. Bassler, H. A., Flood, S. J. A., Livak, K. J., Marmaro, J., Knorr, R., and Batt, C. A. 1995. Use of a fluorogenic probe in a PCR-based assay for the detection of Listeria monocytogenes. Appl. Environ. Microbiol. 61:37243728 .
4. Beckenbach, K., Blaxter, M., and Webster, J. M. 1999. Phylogeny of Bursaphelenchus species derived from analysis of ribosomal internal transcribed spacer DNA sequences. Nematology 1:539-548.

5. Bergdahl, D. R. 1988. Impact of pinewood nematode in North America: Present and future. J. Nematol. 20:260-265.

6. Bőhm, J. A., Schubert, R., Bahnweg, G., Adler, N., Nechwatal, J., Oehlmann, R., and Obwald, W. 1999. Real-time quantitative PCR: DNA determination in isolated spores of the mycorrhizal fungus Glomus mosseae and monitoring of Phytophthora infestans and Phytophthora citricola in their respective host plants. J. Phytopathol. 147:409-416.

7. Bolla, R. I., and Boschert, M. 1993. Pinewood nematode species complex: Interbreeding potential and chromosome number. J. Nematol. 25:227-238.

8. Cheng, H. R., Lin, M. S., and Qian, R. J. 1986. A study on the morphological diagnosis and the pathogenicity of Bursaphelenchus mucronatus. (In Chinese) J. Nanjing Agric. Univ. 2:55-61.

9. Dwinell, L. D. 1997. The pinewood nematode: Regulation and mitigation. Annu. Rev. Phytopathol. 35:153-166.

10. Evans, H. F., McNamara, D. G., Braasch, H., Chadoeuf, J., and Magnusson, C. 1996. Pest risk analysis for the territories of the European Union on Bursaphelenchus xylophilus and its vectors in the genus Monochamus. EPPO Bull. 26:199-249.

11. Harmey, J. H., and Harmey, M. A. 1993. Detection and identification of Bursaphelenchus species with DNA fingerprinting and polymerase chain reaction. J. Nematol. 25:406-415.

12. He, S. S., Wen, W. Q., Yang, L. Y., Xu, Y., and Gu, J. F. 2002. The quick detection of Bursaphelenchus xylophilus by PCR. (In Chinese) Plant Quar. 16:321-324.

13. Heild, C. A., Stevens, J., Livak, K. J., and Williams, P. M. 1996. Real time quantitative PCR. Genome Methods 6:986-994.

14. Holland, P. M., Abramson, R. D., Watson, R., and Gelfand, D. H. 1991. Detection of specific polymerase chain reaction product by utilizing the $5^{\prime} \rightarrow 3^{\prime}$ exonuclease activity of Thermus aquaticus DNA polymerase. Proc. Natl. Acad. Sci. USA 88:7276-7280.

15. Hoyer, U., Burgermeister, W., and Braasch, H. 1998. Identification of Bursaphelenchus species (Nematoda, Aphelenchoididae) on the basis of amplified ribosomal DNA (ITS-RFLP). Nachrichtenbl. Deut. Pflanzenschutzd. 50:273-277.

16. Iwahori, H., Kanzaki, N., and Futai, K. 2000. A simple polymerase chain reaction restriction fragment length polymorphism-aided diagnosis method for pine wilt disease. For. Pathol. 30:158-165.

17. Kanzaki, N., and Futai, K. 2002. A PCR primer set for determination of phylogenetic relationships of Bursaphelenchus species within the xylophilus group. Nematology 4:35-41.

18. Kiyohara, T., and Tokushige, Y. 1971. Inoculation experiments of a nematode Bursaphelenchus sp. onto pine trees. J. Jpn. For. Soc. 53:210-218.

19. Mamiya, Y. 1984. The pinewood nematode. Pages 589-626 in: Plant and Insect Nematodes. W. R. Nickle, ed. Marcel Dekker, New York.

20. Mamiya, Y., and Enda, N. 1979. Bursaphelenchus mucronatus n. sp. (Nematoda: Aphelenchoididae) from pinewood and its biology and pathogenicity to pine trees. Nematologica 25:353-361.

21. Matsunaga, K., and Togashi, K. 2004. A simple method for discriminating Bursaphelenchus xylophilus and B. mucronatus by species-specific polymerase chain reaction primer pairs. Nematology 6:273-277.

22. Mota, M. M., Braasch, H., Bravo, M. A., Penas, A. C., Burgermeister, W., Metge, K., and Sousa, E. 1999. First report of Bursaphelenchus xylophilus in Portugal and in Europe. Nematology 1:727-734.

23. Robbins, K. 1982. Distribution of the pine wood nematode in the United States. Pages 3-6 in: Proceedings of the National Pine Wilt Disease Workshop. J. E. Appleby and R. B. Malek, eds. Illinois Natural History Survey, Champaign, IL.

24. Shen, B. K., and Cao, Y. 1995. A report on occurrence of pine wilt disease in recent 10 years and its forecast and countermeasure. (In Chinese) J. Anhui Agric. Univ. 22:65-68.

25. Smith, I. M. 1985. Pests and disease problems in European forests. FAO Plant Prot. Bull. 33:159-164.

26. Tajima, K., Aminov, R. I., Nagamine, T., Matsui, H., Nakamura, H., and Bennoy, Y. 2001. Diet-dependent shifts in the bacterial population of the rumen revealed with real-time PCR. Appl. Environ. Microbiol. 67:27662774.

27. Wang, Y., Wang, L. F., Yu, S. P., Yang, B. J., and Hu, X. Q. 1999. Establishment of optimal conditions for Bursaphelenchus xylophilus RAPD analysis. (In Chinese) J. Yunnan Agric. Univ. (Suppl.) 14:12-16.

28. Webster, J. M., Anderson, R. V., Baillie, D. L., Beckenbach, K., Curran, J., and Rutherford, T. A. 1990. DNA probes for differentiating isolates of the pinewood nematode species complex. Rev. Nématol. 13:255-263.

29. Weller, S. A., Elphinstone, J. G., Smith, N. C., Boonham, N., and Stead, D. E. 2000. Detection of Ralstonia solanacearum strains with a quantitative, multiplex, real-time, fluorogenic PCR (TaqMan) assay. Appl. Environ. Microbiol. 66:2853-2858. 
30. Yi, C., Park, J., and Chang, K. 1989. Occurrence of pinewood nematode, Bursaphelenchus xylophilus (Steiner \& Buhrer) Nickle, and its vector, Monochamus alternatus Hope, in Korea. Pages 183-193 in: Proc. IUFRO Reg. Workshop For. Insect Pests and Tree Dis. in NE Asia. For. Prod. Res. Inst., Tsukuba, Japan.

31. Zarlenga, D. S., and Higgins, J. 2001. PCR as a diagnostic and quantitative technique in veterinary parasitology. Vet. Parasitol. 101:215-230.

32. Zhang, L. H., Lian, J. L., and Feng, Z. X. 2001. Sequencing and PCRSSCP analysis of ribosomal and of Bursaphelenchus nematodes. Acta Phytopathol. (In Chinese) Sinica 31:84-89.
33. Zhao, B. G., Wang, H. L., Han, S. F., and Zheng, M. H. 2003. Distribution and pathogenicity of bacteria species carried by Bursaphelenchus xylophilus in China. Nematology 5:899-906.

34. Zheng, J. W., Subbotin, S. A., He, S. S., Gu, J. F., and Moens, M. 2003. Molecular characterisation of some Asian isolates of Bursaphelenchus xylophilus and Bursaphelenchus mucronatus using PCR-RFLPs and sequences of ribosomal DNA. Russ. J. Nematol. 11:17-22.

35. Zheng, J. W., Xu, J. P., Wu, Y. L., and Li, D. B. 1998. RAPD fingerprinting on inter- and infra-species of Bursaphelenchus xylophilus and Bursaphelenchus mucronatus. (In Chinese) J. Zhejiang Agric. Univ. 24:597-601. 